\title{
sciendo
}

\section{Evaluation of the Efficiency of Public Support for Cluster Organizations in THE CZECH RePUblic}

\author{
Miroslav Žižka1, Vladimíra Hovorková Valentová ${ }^{2}$, \\ Natalie Pelloneová ${ }^{3}$, Eva Štichhauerová ${ }^{4}$
}

\begin{abstract}
The research presented in the paper aims to find out whether the public support (subsidies) received by cluster organizations for their development and activities is efficient. That means whether the state receives a return on investment in the form of increased revenues to public budgets. The research was conducted on a sample of seven cluster organizations that include the following sectors: furniture, packaging and textile production, engineering, the automotive industry, IT and nanotechnology. For each cluster organization, the data on subsidies was drawn from the moment of their establishment until 2017. At the same time, a list of the cluster member organizations was drawn up, with financial data being collected only for business entities. For each enterprise, information about paid corporate income tax, income tax on employment from employee wages, and social and health insurance paid by the companies and their employees was collected. In the next phase, increases in taxes and insurances were monitored and compared to the year in which the cluster organization drew a subsidy for the first time. Subsequently, the public support efficiency rate and payback period were calculated. The research results show that public support for cluster organizations is efficient, with a relatively short payback period.
\end{abstract}

\section{Keywords}

Cluster, Cluster Organization, Cluster Initiative, Public Support, Efficiency, Payback Period

\footnotetext{
${ }^{1}$ Technical University of Liberec, Studentská 2, 46117 Liberec, Czech Republic. E-mail: miroslav.zizka@tul.cz.

2 Technical University of Liberec, Studentská 2, 46117 Liberec, Czech Republic.

E-mail: vladimira.valentova@tul.cz.

3 Technical University of Liberec, Studentská 2, 46117 Liberec, Czech Republic. E-mail: natalie.pelloneova@tul.cz.

4 Technical University of Liberec, Studentská 2, 46117 Liberec, Czech Republic.

E-mail: eva.stichhauerova@tul.cz.
} 


\section{Introduction}

In the current economy, enterprises not only compete with each other, but they often also cooperate with the participation of other research and educational institutions. The term cluster is used for such form of cooperation in a particular sector and region. Clusters can originate naturally or as a result of a target-oriented cluster initiative (see Section II). The idea of clustering was introduced at the beginning of the 1990s by Michael Porter, who built on the concept of Alfred Marshall's industrial districts and interconnected it with strategic management theory. In the mid-1990s, a target-oriented cluster policy began to develop particularly in EU countries; and since approximately 2000, it has become a part of mainstream regional policy. Nowadays, clusters are one of the tools used in regional, industrial and innovation policies of the EU and its member states (Ketels, 2017).

In the Czech Republic, cluster initiatives have been supported since 2004, when the Government approved the CLUSTERS sub-programme within the Operational Programme Industry and Enterprise 2004-2006. Under this sub-programme, 42 projects for searching for clusters with a subsidy totalling CZK 47 mil. and 12 projects for establishing clusters with a subsidy of CZK 140 mil. were supported (The Ministry of Industry and Trade, 2010). In the following 2007-2013 programming period, clusters were supported in the Operational Programme Enterprise and Innovation from the Cooperation - Clusters sub-programme. Under this sub-programme, 39 projects with a total subsidy of CZK 1.074 billion were supported (CzechInvest, 2020). This support was mostly aimed at the development of clusters, support for innovation and joint projects of member entities. In the latest 2014-2020 programming period, clusters are supported from the Operational Programme Enterprise and Innovation for Competitiveness. The Cooperation sub-programme is designed for the development of research and development activities, particularly of SMEs, the establishment of shared research infrastructure and the internationalization of clusters. As of March 2019, 91 projects with the total amount of CZK 550 mil. have been supported from this sub-programme (API, 2019).

The statistics on the drawing of subsidies show that more than CZK 1.8 billion (approx. EUR 70 mil.) have been spent on supporting the establishment, development and activities of cluster organizations in the Czech Republic since 2004. The research presented in the paper aims to determine whether this public support for cluster organizations is efficient. This means whether the state receives a return on investment in the form of increased revenues to public budgets.

\section{The Importance and Role of Clusters, Cluster Initiatives and Cluster Organizations}

Alfred Marshall ([1890], 1920a) described in his work that industries tend to localize to places with convenient physical conditions (work, soil, water, climate). He also observed that in such places, knowledge and ideas spill over from one person to another. Other companies supplying materials and tools or organizing transport are created in the locality. Marshall used the term industrial district for the geographic concentration of specialized industries. Marshall explained the development of industrial districts due to the existence of 
positive externalities in concentrated and interconnected companies and industries. These externalities are triggered by hereditary skills, the growth of subsidiary trades, the use of highly specialized machinery, the local market for special skills, an industrial atmosphere and leadership and the introduction of novelties (Marshall, 1920a; Marshall, 1920b). Marshall's concept of industrial districts states the existence of dynamic complementarity within a system of interdependent economic entities. He expects that a cluster of industrial companies will perform better than the sum of its individual units in a more scattered distribution of companies. Several other scientists have built upon Marshall's work. For example, one of them was the economist Becattini (1979), a representative of the so-called Italian school, who analysed successful Italian regions and subsequently examined the differences in their development.

The term "cluster", which was popularized by Michael Porter in the 1990s, is also based on a geographic concentration of enterprises in a certain industry. Porter (1998, p. 78) formulated the definition of a cluster as follows: "Clusters are geographic concentrations of interconnected companies and institutions in a particular field. Clusters encompass an array of linked industries and other entities important to competition. They include, for example, suppliers of specialized inputs such as components, machinery, and services, and providers of specialized infrastructure. Clusters also often extend downstream to channels and customers and laterally to manufacturers of complementary products and to companies in industries related by skills, technologies, or common inputs. Finally, many clusters include governmental and other institutions - such as universities, standardssetting agencies, think tanks, vocational training providers, and trade associations - that provide specialized training, education, information, research, and technical support". Compared to Marshall's industrial districts, Porter's research is more focused on the synergic effects of cooperation between groups of companies and research institutions, whether public or private. Also, the definition of a region or locality is much broader with Porter (Belussi and Caldari, 2008). According to Porter's concept (2000), a region can be understood as a city, state or even neighbouring areas of two states. Porter combined the microeconomic theory of competition and the role of localization in creating a competitive advantage. He created a model explaining the effect of localization on competition using four interconnected influences that he graphically portrayed as a diamond. These attributes are: factor conditions, demand conditions, related and supporting industries, firm strategy, structure, and rivalry. Together, these attributes create an environment in which enterprises are created and learn how to compete with one another (Porter, 1990). However, Motoyama (2008) does not consider the concept of interconnected enterprises and the definition of agglomeration effects to be the fundamental contribution of Porter's cluster theory. $\mathrm{He}$ states that e.g. the impact on innovation had already been examined by Schumpeter. Motoyama (2008) regards the following factors as the main reasons for the success of Porter's concept: a simple explanation, a clear direction (marketing) and political justification. Porter does not promote clusters as only a theoretical concept; rather, he has made them one of the key instruments of regional policy. Politicians, organizations such as OECD and the World Bank, national governments and their institutions such as 
development agencies started promoting the establishment and development of clusters on the basis of Porter's theory (Martin and Sunley, 2003).

A cluster can originate quite naturally on the basis of market developments or its creation can by supported through a cluster initiative. Cluster initiatives are organized efforts targeted at creating clusters and increasing the growth and competitiveness of clusters in a region with the participation of cluster companies, the government or the research community (Lindqvist, Ketels and Sölvell, 2013; Andersson, Schwaag-Serger, Sörvik and Wise, 2004). The approach based on the prime role of private actors in the creation of a cluster and their natural cooperation with universities and the government is referred to as bottom-up. Conversely, if the formation of a cluster is initiated by the government and is the result of public policy and public funding, it is referred to as the top-down approach (Fromhold-Eisebith and Eisebith, 2005). According to research conducted by Sopoligová and Pavelková (2017), the bottom-up approach prevails in Europe today, while the top-down approach to supporting clusters is more common in Asian countries.

The result of a cluster initiative is the establishment of a cluster organization. It represents a formalized entity, which originates from a cluster initiative, supports cluster development and provides various services to member organizations (Pavelková, 2009). A cluster organizations acts as an intermediary between different members of the cluster, organizes various cluster activities, and stimulates cooperation both within the cluster and between the cluster and the outside world (Schretlen, Dervojeda, Jansen and Schaffmeister, 2011). The largest worldwide survey of cluster initiatives and organizations was conducted in the Greenbook (Lindqvist, Ketels and Sölvell, 2013). It includes 356 cluster organizations in 50 countries around the world. It was found that $41 \%$ of cluster initiatives were triggered by public programmes. The most common objectives of cluster organizations are to promote brand and identity, strategy and vision, to support innovation, research and development, and to improve the business environment.

It is clear from the above text that clusters are supported quite significantly from public resources. Cluster support then represents a political intervention aimed at creating, mobilizing or strengthening one or more clusters (Boekholt, Arnold, Giarracca and Ploeg, 2014). In general, cluster support can take the following forms: direct funding of a cluster organization, funding of projects of cluster organizations created from a cluster initiative, and strengthening framework conditions for their development (Boekholt, Arnold, Giarracca and Ploeg, 2014). Public interventions can be broad or very narrow; they can have the nature of regularly recurring activities as well as being one-off projects. In recent decades, clusters have been widely used as a tool to increase competitiveness at the regional and national levels. Their existence is associated with agglomeration economies, knowledge spillover, stimulation of innovation, increased productivity, efficiency and operational performance, positive economic impacts on the region (new investments, establishment of new companies, capital inflow, economic growth), social benefits (such as cooperation between the private and public sectors, growth of the region's attractiveness) and others (Hernández-Rodríguez and Montalvo-Corzo, 2012). A cluster simply interconnects all the basic components - resource availability and the individual members' objectives - to achieve competitive success, and shares the ideas of proximity, 
networks and specialization. Clusters stimulate and revive both formal and informal cooperation in the area of business environment (Boekholt, Arnold, Giarracca and Ploeg, 2014). They stimulate competitive pressure, even between indirect competitors or non-competing participants (Bialic-Davendra, 2011). Obadic (2015) emphasizes that the benefits of cluster cooperation include lower transaction costs and more efficient public decisions concerning infrastructure, education and financial resources.

Critical opinions on cluster policy can also be found in the literature. For example, Kukalis (2010) examined the financial performance of a total of 194 companies operating in the pharmaceutical and computer chip manufacturing industries. The aim of the research was to verify the hypothesis that the financial performance of companies in a cluster (ROA and ROS indicators) is higher than that of competing companies situated outside the cluster. Data on financial performance for a period of 31 years were examined. The conducted research did not show any link between the financial performance of companies and their membership in a pharmaceutical or computer cluster. In his empirical study, Ruland (2013) examined a sample of more than 4,000 companies from 86 different industries and compared the profitability of enterprises in industrial clusters and of non-member companies in other locations using the ROA indicator. The results of the conducted research showed that, especially in smaller companies, the profitability of cluster members was considerably lower than that of companies that had decided not to join the cluster. No significant difference was found in the profitability for the sample of large companies. Ruland (2013) concludes that smaller companies should carefully evaluate the decision to join an industrial cluster. This conclusion is also supported by a study carried out on SMEs in Croatian hotel clusters. Small companies in the cluster did not show higher productivity, efficiency, service quality, market share or market potential compared to companies outside clusters (Krželj Čolović, Milić Beran and Vrdoljak Raguž, 2016). Many scientists also argue over whether companies in clusters are more or less innovative than non-clustered companies. For example, in their research of a textile cluster, Khan and Gani (2004) critically assess the importance and role of the cluster in facilitating technological innovation and entrepreneurship. There are a number of empirical studies which prove that enterprises in a cluster may have a greater tendency to innovate. However, the innovativeness of a cluster as a whole remains questionable, especially because it is difficult to measure (Zhao, Zhou, Hüsig and Vanhaverbeke, 2010).

However, the questionable benefits of clustering may also be due to the fact that, according to a study by Jirčíková, Pavelková, Bialic-Davendra and Homolka (2013), it has been proved that activities of cluster organizations depend on the life cycle stage. It was found that significant (positive) changes in the functioning of a cluster organization occur only after five years of its establishment.

As stated by Lindqvist, Ketels and Sölvell (2013), a significant portion (41\%) of cluster organizations have been created with public support, and public resources are also a significant source (54\%) of the funding of cluster organizations' activities. Yet, there is not enough research in the literature which addresses the efficiency of public support for cluster organizations. 
The cluster development process and efforts to support it are complex activities and involve both individual and group decision-making (Giuliani, Maffioli, Pacheco, Pietrobelli and Stucchi, 2013). The results will always depend on the level of co-ordination achieved and on the measures taken as a result of better co-ordination and the identification of the relevant actors' strategies.

Public officials and other involved parties are interested in making rational, fair and economical decisions. For this reason, it is necessary to carry out an assessment in order to identify and assess what the government intervention has caused, brought or changed. A number of authors have so far addressed the assessment of the impact and effectiveness of cluster policy, but there has been no uniform approach to this matter yet. According to Sölvell (2008), the assessment of a cluster programme is based on a careful evaluation of the administrative procedures and impacts of ongoing or completed public interventions, in order to obtain feedback and improve future actions.

Assessing the impact and effectiveness of cluster policy serves to legitimize policy measures by demonstrating their effects (Guy, 2003). Cluster policy assessment is essential to ensure the best use of public resources, the responsibility of policy makers and, above all, to feed the necessary learning to improve the design and implementation of public policies (Maffioli, Pietrobelli and Stucchi, 2016).

There is no unanimous opinion among experts on what should be the subject of assessment in the field of cluster policy. For example, Sölvell (2008) argues whether the assessment should focus on the programme itself or on its impact on the cluster organization.

Furthermore, it is necessary to decide whether to focus the assessment on the individual participants in the support programme (enterprises whose performance should be strengthened by cluster development) or on the development of a supported cluster organization or on the region of its operation (Schmiedeberg, 2010; Boekholt, Arnold, Giarracca and Ploeg, 2014).

Cluster policy measures require diverse and multidimensional processes which require a wide range of tools (Maffioli, Pietrobelli and Stucchi, 2016) to be understood and assessed. To evaluate cluster support, it is important to select appropriate evaluation criteria and indicators (Boekholt, Arnold, Giarracca and Ploeg, 2014).

In this context, Sölvell (2008) formulated a number of questions that need to be answered before the evaluation, e.g.: How can the real impact be identified and measured? Based on what standards can success, failure or satisfactory performance be stated? Did the programme lead to any effects and were the effects really such as had been intended? It is necessary to consider whether there are also unplanned effects and whether these occurred due to the intervention programme or on the basis of other explanatory factors.

According to Schmiedeberg (2010), it is important to distinguish between economic indicators (e.g. growth of profit, productivity or GDP growth) and technology indicators (e.g. research and development, patent activities, cooperation agreements) when making an evaluation.

The monitoring and evaluation of cluster organizations, cluster programmes and cluster policies is very important, but the methods used, key performance indicators and data collection vary considerably from country to country (Christensen, Lämmer-Gamp and 
Meier zu Köcker, 2012). There is no single set of agreed evaluation and impact assessment methods yet.

Schmiedeberg (2010) proposes developing case studies and applying econometric models to evaluate cluster policies. When processing case studies, it is necessary to consider not only the circumstances of the cluster development, but also the specifics of the analysed entities and their position and function in the evaluated cluster. The disadvantage is that the conclusions drawn from the case studies cannot be generalized. The strength of an econometric analysis of the impact of the political support for clusters lies, according to Andersson, Schwaag-Serger, Sörvik and Wise (2004), in the ability to distinguish between significant political impacts and parallel circumstances independent of political measures. Boekholt, Arnold, Giarracca and Ploeg (2014) suggest the use of two groups of methods for making cluster policy analyses. First, they recommend the use of data obtained from monitoring reports and surveys to analyse how well cluster measures have met the objectives and to determine the extent to which individual cluster participants have used the results. Second, they propose the use of systemic approaches (including analyses of inputs and outputs). These offer a comprehensive assessment and allow the user to see whether the cluster has positively affected the regional economy. The authors consider online questionnaire surveys (sent directly to cluster members or cluster managers) as a cost-effective method. They also favour the possibility of applying econometric methods to evaluate the impact of cluster measures on participating companies. However, they admit considerable demands in terms of data security and the methodological basis and that positive results only become evident several years after the end of the intervention measures that were taken.

Giuliani, Maffioli, Pacheco, Pietrobelli and Stucchi (2013) offered an overview of methods that can answer, using reliable quantitative evidence, the question of whether cluster support programmes work, are effective in achieving results, and whether they affect business development. The authors first introduced the Social Network Analysis method, which can be used to assess the development of co-ordination between actors, and to explore the nature of the structures, ties and positions that each actor occupies within the network. A case study from Argentina (Giuliani, Matta and Pietrobelli, 2016) showed that the cluster development programme led to a change in the nature of the network before and after the programme's implementation. The network became more centralized. Core businesses were identified as dominant actors, visionaries and motivated entrepreneurs who invest time and resources in network supporting initiatives. These companies were vital in guaranteeing the network's interconnectivity and in creating links between participating and untreated companies. The mentioned programme also led to the strengthening and creation of a new technology transfer between companies from the electronics industry and other local, regional and national institutions. Giuliani, Maffioli, Pacheco, Pietrobelli and Stucchi (2013) propose in the next stage evaluating the expected impacts of implementing measures within the framework of cluster support programmes using efficiency indicators, productivity indicators, export-related indicators, innovationrelated indicators and employment-related indicators. They point out that the proposed 
quantitative tools should be considered as complementary and possibly complementing each other.

Uyarra and Ramlogan (2012) assessed a set of implemented evaluations of cluster policy programmes and measures to capture both the range of evaluations and their outputs. They noted that many evaluations focus only on the measurement of a performance sub-element at the enterprise, region or cluster organization levels. The methods, tools and indicators used vary from case to case and cover different time periods (cluster life cycle, transition period, medium term, ex-post). However, Uyarra and Ramlogan (2012) found some common elements. In many cases, programmes provided an appropriate framework for mobilizing resources and actors to support the innovation potential of the target region and industry. Many clusters include the provision of a broad range of business support services (e.g. assistance for technical innovation and mentoring support) which are strongly linked to cluster productivity, especially for SMEs. Only in some programmes was a strong effect identified in the form of the additional creation of networks and synergies. Implementation aspects and, in particular, the key competencies of cluster managers proved to be key to successful interventions. Involving the private sector in government structures has a positive outcome on strategic directions. High-tech clusters prove to be better at obtaining private sector finances than clusters in traditional industries.

Fornahl et al. (2015) compared empirical evaluation studies focused on cluster policy measures in Germany. According to their conclusions, only a small part of all cluster policy measures were systematically evaluated by external institutions. The compared studies were mostly of an interim-evaluation nature, often aimed at improving existing measures rather than analysing the effects on the economy. Therefore, qualitative rather than quantitative methods are strengthened. Positive effects of cluster policy measures were reported exceptionally. Practically no negative results of the evaluation were clearly identified. Great differentness in, and therefore a limited possibility of comparing different evaluations was observed. In order to make a comparison at least in terms of the quality of evaluation, they recommend focusing on best practices for making evaluations.

Maffioli, Pietrobelli and Stucchi (2016) made a comparison of case studies from the Latin American region, in which they explored both the direct and indirect effects of cluster support programmes. In one study, a direct positive impact on employment, total export value and the likelihood of exporting was identified and it was proved that these effects continued to increase several years after policy implementation. Another study demonstrated a significant impact on business performance (sales, employment, wages and the likelihood of exporting). A case study from Argentina and Brazil showed significant indirect effects of the cluster support programme (growth of sales for untreated companies in Argentina, growth in the value of total exports and the likelihood of exporting in Brazil). These indirect effects still existed 6 years after the commencement of the programme. Crass, Rammer and Aschoff (2016) examined German SMEs participating in an innovation support programme in 2007-2010. The control sample was made up of companies not applying for support. The programme was not specifically aimed at supporting clusters. However, the authors examined the cluster effect with the assumption that companies localized in clusters would be more interested in participating in the programme. This 
assumption was confirmed. However, another assumption, that clustering would increase the intensity of R\&D and sales of new products, was not confirmed. Based on the research results, it can be stated that clustering does not increase the efficiency of public resources invested in innovation support.

In the Czech Republic, the indicator of the effectiveness of public support was used, among other things, for the purposes of evaluating the real benefits of SME support programmes supported by the Czech-Moravian Guarantee and Development Bank. It was given by the proportion of the total amount of the increase in value added for the first to third calendar years of the provision of support to the amount of public support. The result could be interpreted as a multiple of the actually generated increase in value added to the unit of public support provided. Most recently, this indicator was used to assess the benefits from support provided in 2004 (The Ministry of Industry and Trade, 2007).

An evaluation project commissioned by MIT will be prepared by June 2019 to evaluate how support from the European Structural and Investment Funds has contributed to achieving specific objective 1.2 within the Operational Program Enterprise and Innovation for Competitiveness, i.e. to increase the intensity and effectiveness of cooperation in research, development and innovation. Among other things, the evaluation will allow assessing whether the planned results for the Cooperation sub-programme (The Ministry of Industry and Trade, 2016) were actually achieved through supported interventions.

\section{Data and Methodology}

Within the framework of research, a database of cluster organizations in the Czech Republic was created through a search. As of 5 February 2019, 113 cluster organizations have been registered in the Czech Republic, of which only 78 were active. Seven cluster organizations that represent traditional (textile, furniture, packaging, engineering, automotive) and modern (ICT, nanotechnology) industries were selected for the research. At the same time, the selected cluster organizations are important recipients of public support. Since 2006, they have received subsidies totalling CZK 602 mil. The cluster organizations that were selected have been in existence for a sufficient period of time, i.e. they were established at the time of preparation or after the launch of the first supporting subsidy programme. This means that the positive economic effects of the cluster's existence should already be evident (see research by Jirčíková, Pavelková, Bialic-Davendra and Homolka, 2013). The only exception is the nanotechnology cluster that was founded later. It was included in the research to represent an advanced technology industry. The basic characteristics of the cluster organizations are listed in Table 1. A list of members was compiled for each cluster. The cluster organizations' websites served as the source of the membership base data.

The research process can be divided into the following steps:

1. An overview of received subsidies for cluster organizations - the information system CEDR (Central Register of Subsidies), which is operated by the General Financial Directorate (2019a), served as the source of data. Subsidies received by the cluster organization during its existence until 2017 were examined. 
2. The collection of financial statements from the member enterprises - for all business entities that were members of the cluster organization, a profit and loss statement was sought. The analysed period begins with the year when the cluster organization first started drawing their subsidy and ends in 2017. Most companies have not yet published their financial statements for 2018. The commercial database MagnusWeb (Bisnode, 2019), which contains financial statements of enterprises in the Czech Republic, served as the source of data. However, financial statements were missing in several years for some companies. In such case, the statements were searched for in the Collection of Documents of the Companies Register (Department of Justice, 2019). A total of 67 statements were found in the Collection of Documents. If, after this step, isolated missing values remained in the time series, they were supplemented using statistical methods. Trend analysis was used in combination with the pseudo-forecast method to supplement the missing values. It is necessary to distinguish between a function suitable for describing the development of the values of the time series and a function suitable for forecasting future development of the time series. In some time series, especially in corporate income tax time series, it was not possible to find a suitable trend function. In such case, one of the methods that is usually recommended for supplementing values that do not have the nature of time series was used to supplement the missing values. Most often, the missing values were replaced by the median, as the variation of values from many sets was very high. A small portion of the missing values could be replaced by the arithmetic mean. The amount of supplemented data did not exceed the generally recommended value (e.g. Little and Rubin, 2002). By combining different data sources and statistical supplementation of the missing values, a high level of completeness of the time series was achieved. Table 1 shows that financial statements were obtained on average for $89 \%$ of the member companies of the analysed cluster organizations. The remaining enterprises had to be excluded from the analysis because they do not disclose any accounting data or only sporadic data in the time series were detected. According to the Act on Accounting, they are not obliged to disclose their financial statements because they are a natural person not registered in a public register. In practice, however, many businesses do not respect the statutory obligation and do not disclose their financial statements either. According to an analysis by Bisnode (2018), $65 \%$ of companies did not enter accounting documents for 2016 in the Companies Register and $25 \%$ of companies do not do so repeatedly. The success rate of $89 \%$ in obtaining accounting statements is high in this respect. In all cases of missing values, these were micro-enterprises - natural persons conducting business or small companies. The elimination of these enterprises did not significantly affect the validity of the research. 
Table 1: Characteristics of the examined cluster organizations

\begin{tabular}{|l|c|c|c|c|c|}
\hline Name of the cluster & $\begin{array}{c}\text { Legal } \\
\text { form }\end{array}$ & $\begin{array}{c}\text { Year of } \\
\text { establish- } \\
\text { ment }\end{array}$ & $\begin{array}{c}\text { Number of } \\
\text { members }\end{array}$ & $\begin{array}{c}\text { Of which } \\
\text { are business } \\
\text { entities }\end{array}$ & $\begin{array}{c}\text { Number of } \\
\text { analysed } \\
\text { companies }\end{array}$ \\
\hline $\begin{array}{l}\text { Cluster of Czech } \\
\text { Furniture Manufacturers }\end{array}$ & cooperative & 2006 & 30 & 22 & 22 \\
\hline IT Cluster & $\begin{array}{c}\text { registered } \\
\text { society }\end{array}$ & 2006 & 23 & 16 & 13 \\
\hline $\begin{array}{l}\text { OMNIPACK - Cluster } \\
\text { of Industrial Packaging } \\
\text { Manufacturers }\end{array}$ & cooperative & 2005 & 57 & 50 & 44 \\
\hline $\begin{array}{l}\text { Czech Machinery } \\
\text { Cluster }\end{array}$ & $\begin{array}{c}\text { registered } \\
\text { society }\end{array}$ & 2003 & 43 & 34 & 31 \\
\hline $\begin{array}{l}\text { Moravian-Silesian } \\
\text { Automotive Cluster }\end{array}$ & $\begin{array}{c}\text { registered } \\
\text { society }\end{array}$ & 2006 & 76 & 63 & 58 \\
\hline $\begin{array}{l}\text { CLUTEX - Cluster of } \\
\text { technical textiles }\end{array}$ & $\begin{array}{c}\text { registered } \\
\text { society }\end{array}$ & 2006 & 35 & 32 & 25 \\
\hline $\begin{array}{l}\text { NANOPROGRESS - } \\
\text { the Nanotechnology } \\
\text { Cluster }\end{array}$ & $\begin{array}{c}\text { registered } \\
\text { society }\end{array}$ & 2010 & 38 & 35 & 32 \\
\hline
\end{tabular}

Source: own creation (2019)

3. Defining revenue to public budgets from member enterprises of cluster organizations - four types of revenue are considered:

* Due income tax on ordinary activities - was taken from the profit and loss statements of the member enterprises;

* Natural person income tax on employment income - in addition to corporate income tax, which is paid directly by enterprises, the fact is considered that, as a result of the economic activities of member enterprises, the wages of their employees will increase. Employees pay income tax on employment income from these wages. The amount of this tax cannot be determined from the published financial statements. However, the profit and loss statements can be used to determine the labour costs of companies and to estimate on the basis of these costs the amount of paid income tax on employment income. The amount of an employee's income tax depends on many parameters (deductible items from tax bases and tax discounts). Therefore, the following procedure was used to calculate the average wage taxation. The total amount of wages and salaries paid in the national economy was identified in the 2006-2017 time series from the national accounts database which is used for calculating GDP by the income method (The Czech Statistical Office, 2019a). The General Financial Directorate (2019b) publishes data on the collection of individual taxes, including natural person income tax on employment income. From these two figures, the average wage tax rate was calculated, ranging from $9.23 \%$ to $11.09 \%$ in 2006 and 2017 . 
Labour costs determined from the profit and loss statements were multiplied by the average tax rate for each year, and in this way, the income tax on employment income paid by employees of cluster organizations was estimated.

* Social security expenses and health insurance paid by the employer - this is another revenue source for public budgets which has the nature of a mandatory tax in the Czech Republic (taxation of work paid by the employer). Expenses paid for employees can be determined directly from the profit and loss statements for most companies. The statutory insurance rate was $35 \%$ of labour costs until 2008; since 2009, it is $34 \%$. However, the average insurance rate is somewhat lower because some types of labour costs are exempt from insurance. For smaller companies that publish a profit and loss statement in the simplified structure, only personnel costs were available. If the data on insurance paid were not provided, the average insurance rate was used, which was calculated from the data of other companies as social security and health insurance costs divided by personnel costs. The average insurance rate ranged from $30.75 \%$ to $34 \%$ of labour costs in the 2006-2017 period.

* Social security expenses and health insurance of employees - another part of social security and health insurance is deducted from employees' wages. From 2006-2017, the statutory aggregate rate of both insurances ranged from $11 \%$ (since 2009) to $12.5 \%$ (until 2008) of gross wages. Here again, some types of agreements are exempt from insurance. Therefore, a correction coefficient was calculated as the average employer's insurance rate divided by the employer's statutory insurance rate. The employee insurance estimate was calculated as the product of labour costs, the statutory employee insurance rate and the correction factor, always for the given year.

4. Total revenues paid to public budgets - are given by the sum of corporate income taxes, natural person income tax on employment income and social security and health insurance paid by member companies and their employees. The starting base $(t=0)$ is the year when the cluster organization started drawing subsidies for its development. In the following years, increases in taxes and insurance incomes against this base year are monitored.

5. Determination of the efficiency coefficient and payback period - the efficiency coefficient (1) indicates the number of hellers due to increases in tax and nontax revenues (including mandatory insurance) from member companies of a cluster organization per one crown of public support are generated. The payback period (2) measures how many years it will take for the public support to be returned to the state in the form of increased tax and other statutory payments to public budgets. Both indicators can be calculated for all types of revenues or for individual parts.

$$
k_{e f}=\frac{\begin{array}{l}
\sum_{i=1}^{n}\left(\text { tcorp }_{i}-\text { tcorp }_{0}\right)+\sum_{i=1}^{n}\left(\text { tinc }_{i}-\text { tinc }_{0}\right)+\sum_{i=1}^{n}\left(\text { icorp }_{i}-\text { icorp }_{0}\right)+ \\
+\sum_{i=1}^{n}\left(\text { iemp }_{i}-\text { iempl }_{0}\right)
\end{array}}{\sum_{i=0}^{n} \operatorname{subs}_{i}} 100
$$




$$
T_{p b}=\frac{\sum_{i=0}^{n} \operatorname{subs}_{i}}{\frac{\sum_{i=1}^{n}\left(\text { tcorp }_{i}-\text { tcorp }_{0}\right)+\sum_{i=1}^{n}\left(\text { tinc }_{i}-\text { tinc }_{0}\right)+\sum_{i=1}^{n}\left(\text { icorp }_{i}-\text { icorp }_{0}\right)+\sum_{i=1}^{n}\left(\text { iemp }_{i}-\text { iempl }_{0}\right)}{n-1}}
$$

$$
\begin{aligned}
& \operatorname{subs}_{i} \ldots \text { the amount of subsidy received by the cluster organization in year } i \text {, } \\
& \operatorname{tcorp}_{i} \ldots \text { the amount of corporate income tax paid by the member enterprises of the } \\
& \text { cluster organization in year } i, \\
& \operatorname{corp}_{0} \ldots \text { the amount of corporate income tax paid by the member enterprises of the } \\
& \text { cluster organization in the year when the cluster started drawing subsidies } \\
& \text { for the first time, } \\
& \operatorname{tinc}_{i} \ldots \text { the amount of natural person income tax paid by employees of enterprises } \\
& \text { of the cluster organization in year } i, \\
& \operatorname{tinc}_{0} \ldots \text { the amount of natural person income tax paid by employees of enterprises } \\
& \text { of the cluster organization in the year when the cluster started drawing } \\
& \text { subsidies for the first time, } \\
& \operatorname{icorp}_{i} \ldots \text { the amount of social security and health insurance paid by member } \\
& \text { enterprises of the cluster organization for their employees in year } i, \\
& \text { thorp } p_{0} \ldots \text { the amount of social security and health insurance paid by member } \\
& \text { enterprises of the cluster organization for their employees in the year when } \\
& \text { the cluster started drawing subsidies for the first time, } \\
& \operatorname{iempl}_{i} \ldots \text { the amount of social security and health insurance paid by employees of } \\
& \text { member enterprises of the cluster organization in year } i \text {, } \\
& \operatorname{iempl}_{0} \ldots \text { the amount of social security and health insurance paid by employees of } \\
& \text { member enterprises of the cluster organization in the year when the cluster } \\
& \text { started drawing subsidies for the first time, } \\
& n \ldots \text { the number of years from the year when the cluster organization started } \\
& \text { drawing subsidies until } 2017 \text {. }
\end{aligned}
$$

\section{Results of the Research}

Table 2 shows the amount of subsidies received by cluster organizations for both their development and support of joint activities with members during the said period. The seven cluster organizations have received more than CZK 602 mil. in public budget subsidies since 2006. The total increase in taxes and insurances paid by companies and their employees to public budgets was over CZK 32.346 billion. At first glance, it can be therefore stated that the funds spent by the state to support cluster organizations have been returned. At the same time, Table 2 shows that the result is mainly influenced by the automotive cluster balance. Companies in the automotive sector were doing well in the monitored 2011-2017 period; e.g. labour costs increased by more than $80 \%$ over this period. This corresponds to an average rate of growth of labour costs by $10.5 \%$ per year. However, even in the case of other monitored cluster organizations, the increase in revenue that their members have paid to public budgets is higher than the public support paid. 
Table 2: Subsidies received by cluster organizations and revenues paid to public budgets from their members

\begin{tabular}{|c|c|c|c|c|c|c|c|}
\hline $\begin{array}{l}\text { Name of the } \\
\text { cluster }\end{array}$ & $\begin{array}{c}\text { Years of } \\
\text { drawing } \\
\text { subsi- } \\
\text { dies }\end{array}$ & \begin{tabular}{|c} 
Total \\
amount \\
of sub- \\
sidies \\
(CZK \\
mil.)
\end{tabular} & $\begin{array}{c}\text { Increase } \\
\text { in } \\
\text { tcorp } \\
\text { (CZK } \\
\text { mil. })\end{array}$ & $\begin{array}{c}\text { Increase } \\
\text { in tinc } \\
\text { (CZK } \\
\text { mil.) }\end{array}$ & $\begin{array}{l}\text { Increase } \\
\text { in } \\
\text { icorp } \\
\text { (CZK } \\
\text { mil.) }\end{array}$ & $\begin{array}{l}\text { Increase } \\
\text { in } \\
\text { iempl } \\
\text { (CZK } \\
\text { mil.) }\end{array}$ & $\begin{array}{c}\text { Total } \\
\text { increase } \\
\text { in } \\
\text { revenues } \\
\text { paid to } \\
\text { public } \\
\text { budgets } \\
\text { (CZK } \\
\text { mil.) }\end{array}$ \\
\hline $\begin{array}{l}\text { Cluster of } \\
\text { Czech } \\
\text { Furniture } \\
\text { Manufacturers } \\
\end{array}$ & 2010-2017 & 90.168 & 339.606 & 23.349 & -64.969 & -21.252 & 276.734 \\
\hline IT Cluster & $2010-2017$ & 72.155 & 15.844 & 395.859 & $1,099.621$ & 355.752 & $1,867.076$ \\
\hline $\begin{array}{l}\text { OMNIPACK - } \\
\text { Cluster of } \\
\text { Industrial } \\
\text { Packaging } \\
\text { Manufacturers } \\
\end{array}$ & $2006-2015$ & 205.251 & 2.816 & 293.231 & 910.117 & 253.715 & $1,459.879$ \\
\hline $\begin{array}{l}\text { Czech } \\
\text { Machinery } \\
\text { Cluster } \\
\end{array}$ & 2007-2013 & 21.639 & 259.867 & 482.267 & $2,160.896$ & 632.213 & $3,535.242$ \\
\hline $\begin{array}{l}\text { Moravian- } \\
\text { Silesian } \\
\text { Automotive } \\
\text { Cluster } \\
\end{array}$ & $2011-2017$ & 22.350 & $1,875.309$ & $1,644.587$ & $5,046.227$ & $1,635.382$ & $10,201.504$ \\
\hline $\begin{array}{l}\text { CLUTEX - } \\
\text { Cluster of } \\
\text { technical } \\
\text { textiles } \\
\end{array}$ & $2010-2017$ & 85.656 & -8.905 & 124.009 & 250.792 & 78.764 & 444.661 \\
\hline $\begin{array}{l}\text { NANOPRO- } \\
\text { GRESS - the } \\
\text { Nanotechno- } \\
\text { logy Cluster }\end{array}$ & 2012-2017 & 104.962 & 38.760 & 98.418 & 246.398 & 82.276 & 465.853 \\
\hline Total & & 602.181 & $2,523.297$ & $3,061.720$ & $12,327.571$ & $14,434.304$ & $32,346.892$ \\
\hline
\end{tabular}

Source: own creation (2019)

Non-tax revenues from health and social security insurance of employees contributed significantly to the total increase, accounting for $69 \%$ of the total increase in revenues paid to public budgets. By contrast, direct corporate income tax represented only less than $14 \%$ of the total increase. The higher share of non-tax revenues paid to public budgets applies to all cluster organizations, with the exception of the furniture cluster. In the 
period under review, the collection of social security and health insurance declined in the furniture cluster during the monitored period. The decline was due to a reduction in labour costs for member enterprises of the cluster by up to 13\% in the 2010-2015 period. At the same time, the collection of corporate income tax significantly increased in the case of furniture cluster companies. This means that furniture companies increased their production profitability by reducing staff and related labour costs and insurance. For this reason, the increase in income of the furniture cluster is made up of only direct taxes. In the case of one cluster organization - the textile cluster - a decline in the collection of direct corporate taxes was identified. And this is despite the fact that the Czech economy has shown continuous economic growth since 2014 - the aggregate growth of the Czech economy for the 2010-2017 period is $15.6 \%$ (The Czech Statistical Office, 2019b). This points to the fact that profitability in the textile sector has been decreasing over a long period.

The development of individual sources from which taxes and insurances are paid to public budgets is shown in Figure 1. The biggest differences between cluster organizations were found in corporate income tax. The significant increase in corporate tax paid by members of the furniture cluster was accounted for in the text above. Taxes collected from members of this cluster grew at an average rate of $48 \%$ per year. On the contrary, in the textile cluster, it decreased by almost 3\% per year on average. The decline in the rate of the collection of corporate tax, albeit very low (on average less than one per cent per year), was also identified for members of the engineering cluster. Nevertheless, there was a considerable year-on-year fluctuation in the collection of corporate tax for the engineering cluster and, unlike the textile cluster, the sum of increases in the collected tax was positive for the whole 2007-2013 monitored period. The other three sources - natural person income tax, social security and health insurance paid by employers and employees - are dependent on the amount of labour costs and therefore follow the same trend. A more significant increase in these sources was recorded in three clusters - automotive, IT and nanotechnology, on average between $9 \%$ and $12 \%$ per year.

Table 3 evaluates the efficiency (by individual sources of revenue paid to public budgets) and the payback period for public support. On average, the efficiency rate is high, with CZK 3.37 of annual increase in the amount of revenue paid to public budgets from taxes and mandatory insurance per one crown of public support. However, there are significant differences between the individual cluster organizations. In the case of the automotive cluster, the annual increase in the revenue paid to public budgets amounts to CZK 76 per one crown of public support; in the case of the furniture cluster, it is just CZK 0.44. The efficiency rate is especially positively influenced by non-tax revenue from insurances. Taking into account subsidies paid so far for the development and functioning of cluster organizations and the increase in revenue from taxes and insurances that has been theoretically achieved as a result of public support, the payback period for public support is short. The funds spent will return to the state in 0.29 years on average. However, the result is influenced by three clusters - IT, engineering and automotive - which, however, only drew a small part of the subsidies (19\%) but show strong economic results. However, the payback period is short even for other clusters, ranging from one to two years. 
Figure 1: Average rates of growth of tax and non-tax revenues from cluster members

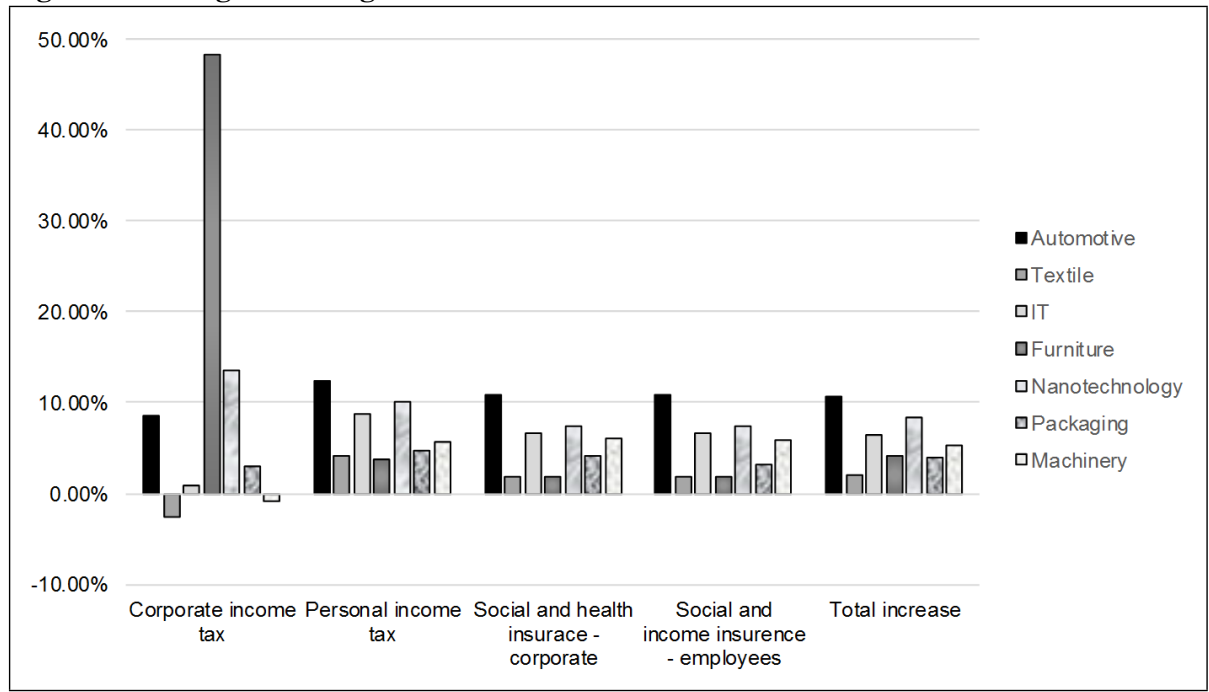

Source: own creation (2019)

Table 3: Efficiency coefficient (\%) and payback period for public support provided to cluster organizations

\begin{tabular}{|l|c|c|c|c|c|c|}
\hline \multicolumn{1}{|c|}{$\begin{array}{c}\text { Name of the } \\
\text { cluster }\end{array}$} & $\begin{array}{c}\text { Total } \\
\text { efficiency } \\
\text { coefficient }\end{array}$ & $\begin{array}{c}\text { Efficiency } \\
\text { coefficient } \\
\text { tcorp }\end{array}$ & $\begin{array}{c}\text { Efficiency } \\
\text { coefficient } \\
\text { tinc }\end{array}$ & $\begin{array}{c}\text { Efficiency } \\
\text { coefficient } \\
\text { icorp }\end{array}$ & $\begin{array}{c}\text { Efficiency } \\
\text { coefficient } \\
\text { iempl }\end{array}$ & $\begin{array}{c}\text { Payback } \\
\text { period } \\
\text { (years) }\end{array}$ \\
\hline $\begin{array}{l}\text { Cluster of Czech } \\
\text { Furniture } \\
\text { Manufacturers }\end{array}$ & 43.84 & 53.81 & 3.70 & -10.29 & -3.37 & 2.28 \\
\hline IT Cluster & 369.66 & 3.14 & 78.37 & 217.71 & 70.43 & 0.27 \\
\hline $\begin{array}{l}\text { OMNIPACK - } \\
\text { Cluster of } \\
\text { Industrial } \\
\begin{array}{l}\text { Packaging } \\
\text { Manufacturers }\end{array}\end{array}$ & 64.66 & 0.12 & 12.99 & 40.31 & 11.24 & 1.55 \\
\hline $\begin{array}{l}\text { Czech Machinery } \\
\text { Cluster }\end{array}$ & $1,633.73$ & 120.09 & 222.87 & 99.86 & 292.16 & 0.06 \\
\hline $\begin{array}{l}\text { Moravian-Silesian } \\
\text { Automotive Cluster }\end{array}$ & $7,607.28$ & $1,398.42$ & $1,226.37$ & $3,762.98$ & $1,219.51$ & 0.01 \\
\hline $\begin{array}{l}\text { CLUTEX - Cluster } \\
\text { of technical textiles }\end{array}$ & 74.16 & -1.49 & 20.68 & 41.83 & 13.14 & 1.35 \\
\hline $\begin{array}{l}\text { NANOPROGRESS } \\
\text { - the Nanotechno- } \\
\text { logy Cluster }\end{array}$ & 88.77 & 7.39 & 18.75 & 46.95 & 15.68 & 1.13 \\
\hline Total & 337.47 & 50.45 & 56.84 & 174.86 & 55.32 & 0.29 \\
\hline
\end{tabular}

Source: own creation (2019) 
The high efficiency rate and the short payback period are influenced by the fact that all the effects that go to public budgets from activities of enterprises, either directly or indirectly, were taken into account. If the efficiency rate and payback period were assessed only from the point of view of direct taxes that member companies pay to the state budget, the efficiency rate would be considerably lower (CZK 0.50 of increase in corporate tax per one crown of support) and the payback period would on average be 1.98 years. However, for example in the case of the textile cluster, support would be irrecoverable, and in the case of the packaging cluster, the payback period would be 802 years.

\section{Conclusion}

This paper attempted to fill in a research gap regarding the efficiency of public support for cluster organizations. In the existing literature, the issue of the impacts of clusters on the innovation and competitiveness of enterprises has been discussed quite extensively, or these impacts are questioned. Other papers deal with evaluating the performance of cluster organizations. Although cluster organizations tend to be recipients of a considerable amount of public support. According to Lindqvist, Ketels and Sölvell (2013), 54\% of revenues of cluster organizations comes from public sources and $41 \%$ of cluster initiatives originated as a result of public policy - research focused on assessing its efficiency is rather unique. One of the reasons may be the very difficult monetary quantification of the results of cluster organizations' activities.

This paper considered a theoretical situation that, as a result of public support for a cluster organization, the financial performance of member enterprises would improve, resulting in a greater collection in the amount of taxes that companies and employees pay to the state budget. The collection of social security and health insurance, which essentially has the nature of a tax in the Czech Republic (although it is officially called a premium), was also considered.

The research results showed that under these assumptions, the support for cluster organizations is efficient and is associated with a short payback period. We cannot ignore the fact that the efficiency rate and the payback period vary for the individual cluster organizations and depend on the industry in which the clusters operate. The main monetary effects of the activities of cluster organizations are reflected mainly in non-tax revenues (insurances), which accounted for $69 \%$ of the total increase in revenues paid to public budgets.

From making a comparison of the public support drawn and the effects obtained, it may seem more relevant for smaller or new sectors. The first group includes the production of textiles, furniture and packaging, which faced economic problems in the monitored period and in which clusters can act as a tool for improving the competitiveness of member enterprises. The new sector is represented by nanotechnology, where a cluster organization can stimulate further research and the application of nanofibers in industry or medicine. On the contrary, in the case of mechanical engineering and the automotive industry, the public support drawn was virtually negligible given the economic strength of the enterprises. 
The authors are aware of the limits of their research. The first fact is there is a limited sample of cluster organizations, which was influenced by the fact that mainly cluster organizations from the first wave of the establishment of clusters were chosen. These clusters are expected to show the economic effects of their cluster membership. Another fact that limited the research is the very complicated access to the financial data of enterprises that often do not respect the disclosure obligation stipulated by the Act on Accounting. The research was also limited by the assumption that performance growth is due to membership in a cluster organization. In fact, many factors influence the performance of an enterprise and membership in a cluster organization is just one of these factors. However, even if the membership of an enterprise in a cluster was a minor factor affecting the performance of the enterprise, the question whether the state will receive the public support back at least in the form of tax and non-tax revenues from member enterprises remains relevant. The presented research gave a positive answer to this question for all seven cluster organizations examined.

Further research can take different directions. The examined sample of cluster organizations can be expanded by adding other sectors, as well as adding the next period. It is also possible to monitor the performance of non-member enterprises in selected industries and to try to estimate the specific impact of cluster organizations on the performance of enterprises. Last but not least, it is also possible to focus on defunct or inactive cluster organizations and to examine what public support they drew and what were the reasons for the cessation of their activities.

\section{Acknowledgements}

Supported by the grant No. GA18-01144S "An empirical study of the existence of clusters and their effect on the performance of member enterprises" of the Czech Science Foundation.

\section{References}

Andersson, T., Schwaag-Serger, S., Sörvik, J., Wise, E. (2004). Cluster Policies Whitebook. Lund: IKED - International Organisation for Knowledge Economy and Enterprise Development.

API. (2019). Statistiky - Stav čerpání z OP PIK. Retrieved March 15, 2019, from https://www.agentura-api.org/wp-content/uploads/2019/03/Sledování-čerpání-alokace-

OP-PIK-13.3.2019.pdf.

Becattini, G. (1979). Dal 'settore' industriale al 'distretto' industriale: alcune considerazioni sull'unità d'indagine dell'economia industriale. Rivista di economia e politica industriale, 5(1), 7-21.

Belussi, F., Caldari, K. (2008). At the origin of the industrial district: Alfred Marshall and the Cambridge school. Cambridge Journal of Economics, 33(2), 335-355. https://doi.org/10/d7wmtt. 
Bialic-Davendra, M. (2011). An Investigation of a new Concept of World-Class Clusters in Europe - A Case Study of the Visegrad Group of Countries. Journal of Competitiveness, 3(2), 43-57.

Bisnode. (2018). Informační ne-povinnost. Retrieved April 14, 2019, from https://www. bisnode.cz/o-bisnode/o-nas/novinky/informacni-ne-povinnost.

Bisnode. (2019). MagnusWeb. Retrieved February 03, 2019, from https://magnusweb.bisnode.cz.

Boekholt, P., Arnold, E., Giarracca, F., Ploeg, M. (2014). Evaluation Reference Model (for TAFTIE's Taskforce Benchmarking Impact, Effectiveness and Efficiency of Innovation Instruments). Amsterdam: Technopolis.

Christensen, T., Lämmer-Gamp, T., Meier zu Köcker, G. (2012). Let's Make A Perfect Cluster Policy and Cluster Programme: Smart Recommendations for Policy Makers. Berlin: VDI/VDE Innovation Technik GmbH.

Crass, D., Rammer, C., Aschoff, B. (2016). Geographical Clustering and the Effectiveness of Public Innovation Programs. Mannheim: Centre for European Economic Research.

CzechInvest. (2019). Statistika čerpání dotací z programu OPPI. Retrieved March 19, 2019, from http://eaccount.czechinvest.org/Statistiky/StatistikaCerpaniDotaci.aspx.

Czech Statistical Office. (2019a). GDP identity from the income side. Retrieved February 22, 2019, from http://apl.czso.cz/pll/rocenka/rocenkavyber.makroek_duchodm_en.

Czech Statistical Office. (2019b). Public database. Retrieved May 09, 2019, from https://vdb.czso.cz/vdbvo2/faces/en/index.jsf.

Department of Justice. (2019). Veřejný restř́k a sbírka listin. Retrieved February 12, 2019, from https://or.justice.cz/ias/ui/rejstrik.

Fornahl, D., Heimer, T., Campen, A., Talmon-Gros, L., Treperman, J., Gerken, P., ... Schrapers, M. (2015). Cluster als Paradigma der Innovationspolitik: Eine erfolgreiche Anwendung von Theorie in der politischen Praxis? (Studien zum deutschen Innovationssystem No. 13-2015). Retrieved from Expertenkommission Forschung und Innovation (EFI) website: http://hdl.handle.net/10419/156623.

Fromhold-Eisebith, M., Eisebith, G. (2005). How to institutionalize innovative clusters? Comparing explicit top-down and implicit bottom-up approaches. Research Policy, 34(8), 1250-1268. https://doi.org/10/bz9vkp.

General Financial Directorate. (2019a). The Central Register of Subsidies (IS CEDR III). Retrieved February 02, 2019, from http://cedr.mfcr.cz/cedr3internetv419/default.aspx. General Financial Directorate. (2019b). Údaje z výběru daní - Vývoj inkasa vybraných daní v $\check{C} R$ v letech 1993-2017. Retrieved February 22, 2019, from https://www.financnisprava.cz/cs/dane/analyzy-a-statistiky/udaje-z-vyberu-dani.

Giuliani, E., Matta, A., Pietrobelli, C. (2016). Networks, Cluster Development Programs, and Performance: The Electronics Cluster in Córdoba, Argentina. In Maffioli, A., Pietrobelli, C., Stucchi, R. (eds.). The Impact Evaluation of Cluster Development Programs: Methods and Practises. Washington: Inter-American Development Bank.

Giuliani, E., Maffioli, A., Pacheco, M., Pietrobelli, C., Stucchi, R. (2013). Evaluating the Impact of Cluster Development Programs. Washington: Inter-American Development Bank. 
Guy, K. (2003). Assessing RTD program portfolios in the European Union. In Shapira P., Kuhlmann, S. (eds.). Learning from Science and Technology Policy Evaluation: Experiences from the United States and Europe. Cheltenham and Northampton: Edward Elgar.

Hernández-Rodríguez, C., Montalvo-Corzo, R. F. (2012). Entrepreneurial clusters in China and Mexico - implications for Competitiveness. Revista Journal, 6(1), 55-90. https://doi.org/10/gfxx65.

Jirčíková, E., Pavelková, D., Bialic-Davendra, M., Homolka, L. (2013). The Age of Clusters and Its Influence on Their Activity Preferences. Technological and Economic Development of Economy, 19(4), 621-637. https://doi.org/10/gfxx87.

Ketels, C. (2017). Two Decades of Cluster Policy Efforts in Europe: Looking Back, Looking Ahead. Presented at the Clusters in Europe IV, Budapest. Retrieved March 20, 2019, from gfpconf.gov.hu/sites/default/files/1.\%20Chrsitian\%20Ketels.pdf.

Khan, J. H., Ghani, J. A. (2004). Clusters and Entrepreneurship: Implications for Innovation in a Developing Economy. Journal of Developmental Entrepreneurship, 9(3), 221-238.

Krželj Čolović, Z., Milić Beran, I., Vrdoljak Raguž, I. (2016). The impact of clustering on the business performance of Croatian SMHEs. Economic Research-Ekonomska Istraživanja, 29(1), 904-913. https://doi.org/10/gfxx86.

Kukalis, S. (2010). Agglomeration Economies and Firm Performance: The Case of Industry Clusters. Journal of Management, 36(2), 453-481. https://doi.org/10/b46w5p.

Lindqvist, G., Ketels, C., Sölvell, Ö. (2013). The Cluster Initiative Greenbook 2.0. Stockholm: Ivory Tower Publishers.

Little, Roderick, J. A., Rubin, Donald, B. (2002). Statistical Analysis with Missing Data (2nd ed.). New Jersey: John Wiley \& Sons, Inc.

Maffioli, A, Pietrobelli, C., Stucchi, R. (2016). The impact evaluation of cluster development programs: Methods and practices. Washington DC: Inter-American Development Bank.

Marshall, Alfred. (1920a). Industry and Trade: A Study of industrial technique and business organization; and of their influences on the condition of various classes and nations (3rd ed.). London: Macmillan and co.

Marshall, Alfred. (1920b). Principles of Economics (8th ed.). Basingstoke: Palgrave Macmillan.

Martin, R., Sunley, P. (2003). Deconstructing clusters: chaotic concept or policy panacea? Journal of Economic Geography, 3(1), 5-35. https://doi.org/10/d97q6p.

Ministry of Industry and Trade (2007). Zpráva o vývoji MSP a jeho podpoře $v$ roce 2007. Př́loha 2: Hodnocení efektivnosti programů podpory malého a středního podnikání na základě realizace projektů podpořených Českomoravskou záruční a rozvojovou bankou. Retrieved May 24, 2019, from https://www.mpo.cz/cz/podnikani/male-a-strednipodnikani/studie-a-strategicke-dokumenty/zprava-o-vyvoji-msp-a-jeho-podpore-v-roce2007--48035.

Ministry of Industry and Trade (2010). Úspěšné projekty v OPPP - program KLASTRY. Retrieved March 20, 2019, from http://www.mpo-oppi.cz/155-uspesne-projekty-vopppprogram-klastry.html. 
Ministry of Industry and Trade (2016). Evaluace a jiné analýzy. Retrieved May 24, 2019, from https://www.mpo.cz/cz/podnikani/dotace-a-podpora-podnikani/oppik-20142020/evaluace-a-analyzy/evaluace-a-jine-analyzy--157435.

Motoyama, Y. (2008). What Was New About the Cluster Theory? What Could It Answer and What Could It Not Answer? Economic Development Quarterly, 22(4), 353-363. https://doi.org/10/b2pf5j.

Obadic, A. (2015). Cluster development and mapping process in Croatia. In I. Vrankic, G. Kozina, V. Kovsca (Eds.), Economic and Social Development. Book of Proceedings. Koprivnica: University North; Varazdin: Varazdin Development and Entrepreneurship Agency.

Pavelková, D. (2009). Klastry a jejich vliv na výkonnost firem. Praha: Grada.

Porter, M. E. (1998). Clusters and the New Economics of Competition. Harvard Business Review, 76(6), 77-90.

Porter, M. E. (1990). The Competitive Advantage of Nations. Harvard Business Review, 68(2), 73-93.

Porter, M. E. (2000). Location, Competition, and Economic Development: Local Clusters in a Global Economy. Economic Development Quarterly, 14(1), 15-34. https://doi.org/10/ fw7s76.

Ruland, W. (2013). Does Cluster Membership Enhance Financial Performance? IBusiness, 5(1), 1-11. https://doi.org/10/gftjgd.

Schmiedeberg, C. (2010). Evaluation of Cluster Policy: A Methodological Overview. Evaluation, 16(4), 389-412.

Schretlen, J.-H., Dervojeda, K., Jansen, W., Schaffmeister, B. (2011). Uncovering excellence in cluster management. Amsterdam: PricewaterhouseCoopers.

Sölvell, O. (2008). Clusters. Balancing Evolutionary and Constructive Forces. Stockholm: Ivory Tower Publishers.

Sopoligová, M., Pavelková, D. (2017). Cluster policy in Europe and Asia: A comparison using selected cluster policy characteristics. Journal of International Studies, 10(3), 35-50. https://doi.org/10/gfxx9k.

Štěpánová, P., Škácha, K. (2018, June 18). Informační ne-povinnost. Bisnode. Retrieved March 21, 2019, from https://www.bisnode.cz/o-bisnode/o-nas/novinky/informacni-nepovinnost.

Uyarra, E., Ramlogan, R. (2012). The Effects of Cluster Policy on Innovation, Compendium of Evidence on the Effectiveness of Innovation Policy Intervention. Manchester: Manchester Institute of Innovation Research.

Zhao, Y., Zhou, W., Hüsig, S., Vanhaverbeke, W. (2010). Environment, network interactions and innovation performance of industrial clusters: Evidences from Germany, The Netherlands and China. Journal of Science and Technology Policy in China, 1(3), 210-233. https://doi.org/10/ffvmbc. 
